edge effect の減少, 広し階調再現性之同時汒線量の低 減も可能となる. 現像電極を設置するととによって得ら れた線量低下分を搪大撮影飞向けるのか（愛媛大・川 上）との質問に対し，コンタクト法と同量の線量で拡大 撮影が可能であり，積極的に拡大撮影を活用するととを 示晙した。ただし，電極方式は初期のXerox 125 system 飞は設置されており，B，C，Dの初期の電位可変以上の 效果が得られなかったとと，現像チャンバ内でのトナー による付着が大きい問題となって取除かれた経過があ り，既存の装置に同様の電極を設置する上で，長期的な 稼動に付随する諸々の影響とついて，是非追試をしてい ただきたい。なお，X線被ばく軽減への努力には敬意を 表したい。

演題236は, 微小石灭化の識別能を高めるため拡大撮影 を応用し，その結果をROC曲線によって評価している。 Film-mammography での拡大撮影は, すでに日常臨床 に応用されているが, Xeroについては被ばく舅の問題 ああって，てれまで消極的であったように思う。特に今 回の報告では， $75 \mu$ 微小焦点を用りた拡大撮影に目新し さがあった．演者の報告および現在のX線管の出力から 判断して，1.5 倍前後が妥当な拡大率であるうかと思う が, いずれにしても Gershon-Cohen によれば，乳癌の 85\%が微小石灰化を有し， mammography では，その35 \%が検出されるに過ぎないといわれており，今後，拡大 撮影に期待するとしろが大きい。コンタクト法と比較し て(愛䟦大・川上) 約3.6倍の線量が必要であると述べて いる.

演題237は，新しく実用化された，KIP法によるX線 電子写真の使用知見とその臨床例执よさ低濃度造影によ る血管撮影への基礎実験について報告した。特て実用機 の改良点しして,プロセッサに多機能性をむたせたて と，フィルム表面のコーティング処時による重送防止お よび誤操作，機械的な異常が生じた場合，異常コードを 表示し内蔵マイクロコンピュータによる常状態に復帰 させる機構等の採用などユーザの二ーズにかなった改良 点がなされたしとを述へててい．現像方式の質問（愛媛 大・川川上）対しては，現時点では 2 成分系の現像方式 を採用しており，一成分系現像方式への改善は今後に残 された課題であろう。円筒ツーブスの使用の有無につい て (厚木病院・斎藤) は，演者汃ら散乱線の影響につい て解答したが，乳腺以外への無駄なX線被ぱくを無くす とと, positioning が容易であるしと（対側乳房の重複 をさける等)，胸壁部に対し垂直な X線入射が得られる などの利点を共同研究者の一人として加筆しておきた
(2).

画像処理-1

坐長 若松孝司 (国立循環器病センター)

\section{8. 写真濃度レベルを視覚検出能の検討}

日本医科大学附属病院放射線科

○村松敏孝・鉿木 洵・川村義彦

円城寺純男 - 町田和夫 ·土橋俊男

[目的] 各コンポーネントについて，ハウレットチャ 一トのパターン伝達特性を求め, 写真濃度レベルを視 覚検出能について検討した。使用つィルムスクリーン DETAIL, HI-SCREEN, QUANTA-II/RX, AOGOH-1/ $\mathrm{KS}, \mathrm{G} 4 / \mathrm{RXO}, \mathrm{G} 8 / \mathrm{RXO}-\mathrm{G}$.

〔結果〕高画質システ公程㝍真素地濃度の変動が画貿 に影響する。高感度システムは適正濃度またはオーバぎ すで画質の維持ができる。同一感度システムでは，粒状 の良りシステム程，多少写真がのンダでもオーバでも画 質レベルは維持される。粒状の悪いシステムは $D=0.9$ 以下で著明に画質が劣下し，高圧では量子モトルの作用 でさらに劣下する.以上今後の臨床技術のあり方にひと つの指標を与えたすのと考える.

239. 島津核医学 データ処理システムシンチパック 2400 による総合画像処理

(株)島津製作所医用機器事業部技術部 ○若林重興

種々の㭘查機器で知られる矦用画像を総合的に処理す る目的で，核医学データ処理システム“シンチパックー 2400” を搪張し，データ採取，処理が行なえるようにし たので報告する。ハードウェアとして開発されたビデオ 入力装置 $(512 \times 512$ マトリックス，256レベル) は US などビデオ信号で出才されるものはオンラインで，X線 フィルム等の画像はTVカメラを通してビデオ信号に したのち，オンラインでそれぞれシンチパックに入力す る. X線 CT 像は磁気テープ等でオンライン入力される. 応用例として腹部につしてX線単純撮影, X線 CT, US, RI の各画像を処理した。相互の関係が明膫になり，診 断上有用であった。

240. フジ・コンピューテッド・ラジオグラフィ・シス テムの基礎的検討 I. R $\mathbf{O} \mathrm{C}$ 曲線を用いた検出力 の評洒

富士フィルム(株)宮台技術開発センター ○中島延淑・古巻隆夫 加藤久豊・高野正雄 